Biogeosciences Discuss., 6, 2755-2784, 2009

www.biogeosciences-discuss.net/6/2755/2009/

(C) Author(s) 2009. This work is distributed under

\title{
Effect of land use on carbon dioxide, water vapour and energy exchange over terrestrial ecosystems in Southwestern France during the CERES campaign
}

N. Jarosz ${ }^{1}$, P. Béziat ${ }^{2}$, J. M. Bonnefond ${ }^{3}$, Y. Brunet ${ }^{3}$, J. C. Calvet ${ }^{4}$, E. Ceschia ${ }^{2}$, J. A. Elbers ${ }^{5}$, R. W. A. Hutjes ${ }^{5}$, and O. Traullé ${ }^{4}$

${ }^{1}$ CESBIO, UMR 5126, CNRS-UPS, 24 rue d'Embaquès, 32000 Auch, France

${ }^{2}$ CESBIO, UMR 5126, CNRS-UPS, 18 avenue Edouard Belin, bpi 2801, 31401 Toulouse cedex 9, France

${ }^{3}$ INRA, UR 1263 EPHYSE, B.P. 81, 33883 Villenave d'Ornon, France

${ }^{4}$ Météo France, 42 avenue Coriolis, 31057 Toulouse, France

${ }^{5}$ Alterra, Droevendaalsesteeg 3, 6708 PB Wageningen, The Netherlands

Received: 30 December 2008 - Accepted: 8 January 2009 - Published: 3 March 2009

Correspondence to: N. Jarosz (nathalie.jarosz@ cesbio.cnes.fr)

Published by Copernicus Publications on behalf of the European Geosciences Union.

Effect of land use on carbon dioxide, water vapour and energy exchange

N. Jarosz et al.

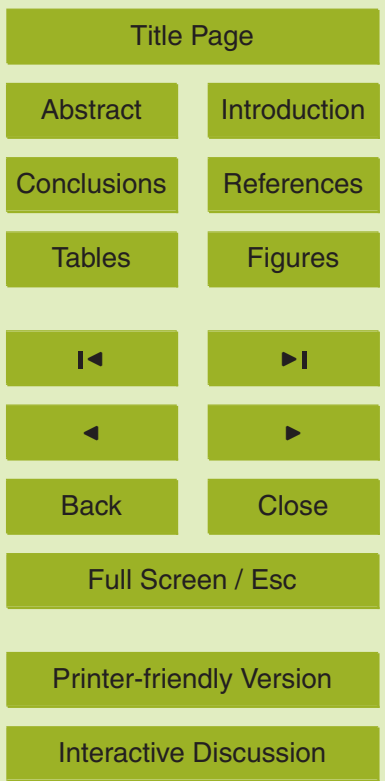




\section{Abstract}

Eddy fluxes were measured over different ecosystems, winter and summer crops, a maritime pine forest at different stages of development and grassland, from 17 May to 26 June 2005 in the southwestern region of France. During the experiment, summer 5 crops started growing whereas winter crops and grassland achieved their senescence. Comparatively, the other ecosystems had a much slower growth emphasized by soil water deficit at forest sites.

The ten ecosystems showed different partitioning of available energy. Net radiation was the highest above the maritime pine forest, followed, in decreasing order, by the crops, the vineyard and the grassland. Over the whole campaign period, the Bowen ratio $(\beta=H / L E)$ was larger above the forest sites than for the other sites.

The various vegetation types also showed contrasting net ecosystem exchange (NEE) dynamics following their growth status and respective behaviour in response to drought. Both the clearcut and summer crops before irrigation and plant growth be15 haved as sources of $\mathrm{CO}_{2}$, whereas the vineyard, the mature forest and winter crops acted as sinks. However the maize crops became substantial sinks of $\mathrm{CO}_{2}$ after the start of irrigation and canopy growth, with fluxes twice as large as for the mature pine forest. Finally, throughout the experiment, forest, grassland and crops sequestrated from about $50 \mathrm{gC} \mathrm{m}^{-2}$ to $230 \mathrm{gC} \mathrm{m}^{-2}$, while the cleacut and the beans crop rejected about $30 \mathrm{gC} \mathrm{m}^{-2}$.

These results support the idea that converting a mature forest to a clearcut or bare soil available to agricultural use enhances the sensible heat flux and shifts the ecosystem from a sink to a source of carbon.

\section{Introduction}

25 Terrestrial ecosystems act as important sources and sinks of mass and energy both locally and regionally. In order to understand climate change and in particular evaluate
BGD

6, 2755-2784, 2009

Effect of land use on carbon dioxide, water vapour and energy exchange

N. Jarosz et al.

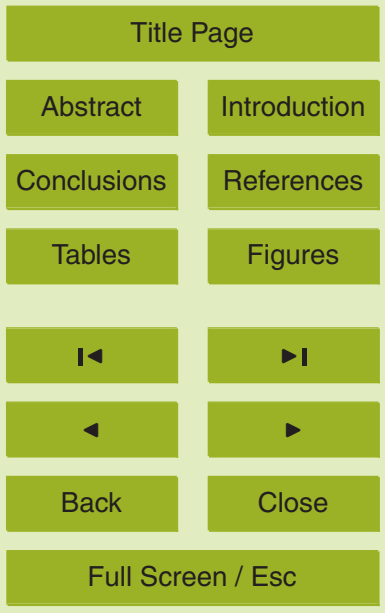

Printer-friendly Version

Interactive Discussion 
the consequences of the continuous increase in atmospheric carbon dioxyde $\left(\mathrm{CO}_{2}\right)$, quantifying sources and sinks of carbon dioxyde, water vapour and energy at the level of whole ecosystems is of great importance.

Land use practices have played a significant role in changing the global carbon cycle 5 (Houghton, 2003) and the regional climates through changes in surface energy and water balance (Kalnay and Cai, 2003). Land use changes also affect regional climates through changes in surface energy and water balance (Pielke Sr., 2005).

In order to understand and quantify the various sources and sinks, the eddycovariance (EC) method has proved to be useful to measure long-term energy and 10 mass exchange at the canopy scale in programmes such as Euroflux (Aubinet et al., 2000) and FLUXNET (Baldocchi et al., 2001). This involves the use of eddy-covariance flux tower systems to measure long-term fluxes of $\mathrm{CO}_{2}$, water vapour and energy.

Many studies have analyzed EC fluxes on forests as they were good potentials to sequester carbon in order to help mitigate the greenhouse effect, but only a few have been devoted to grasslands and croplands. High rate of net carbon uptake have been observed for tropical and temperate forests sites (Granier et al., 2000; Valentini et al., 2000; Aubinet et al., 2001; Berbigier et al., 2001; Pilegaard et al., 2001; Wilson and Baldocchi, 2001). However, some studies revealed that boreal forests lose carbon dioxide (Goulden et al., 1998; Lindroth et al., 1998).

In the last few years, the potential of agroecosystems to sequester carbon has received considerable scientific attention (Vleeshouwers and Verhagen, 2002; Smith et al., 2005; Hutchinson et al., 2007; Seguin et al., 2007). Therefore, EC studies have mostly focussed on carbon exchange over grasslands (Suyker and Verma, 2001; Soussana et al., 2007) and croplands (Suyker et al., 2004; Verma et al., 2005; Moureaux et al., 2006; Aubinet et al., 2009; Béziat et al., 2008). Suyker and Verma (2001) found that a grassland was a source of carbon due to burning but in Europe Soussana et al. (2007) found that sown, intensive permanent and semi-natural grassland were sink of carbon. Aubinet et al. (2009) showed that a complete crop rotation behaved as a sink of carbon and Verma et al. (2005) and Béziat et al. (2008) evidenced that following

BGD

$6,2755-2784,2009$

Effect of land use on carbon dioxide, water vapour and energy exchange

N. Jarosz et al.

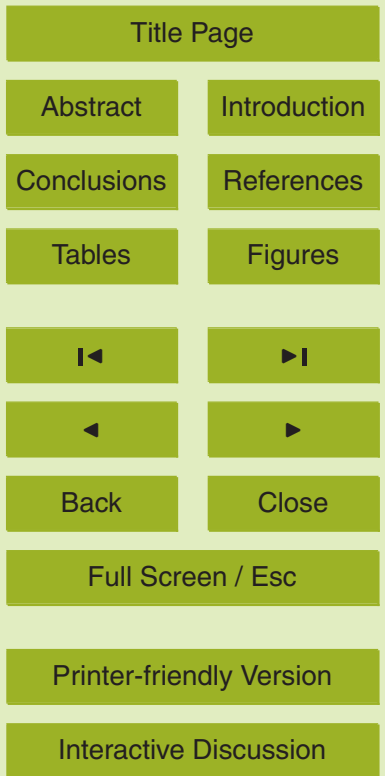


management practises, crop rotation behaved as a nearly carbon neutral or slight carbon source. Most of these measurements have been made in different geographical regions and at different time periods. As the results depend on the meteorological conditions and vary in time it is difficult to compare them directly and evaluate the relative 5 contribution of each ecosystem to regional water and carbon exchanges. Therefore, there is a need to measure fluxes over different types of ecosystem at a given time period, in a given region and with similar meteorological conditions (Sellers et al., 1997; Halldin et al., 1999).

The present study aims at developing a better understanding of mass and energy 10 over various ecosystems typical of Southwestern France. As a contribution to the CarboEurope Regional Experiment Strategy campaign (Dolman et al., 2006), a maritime pine forest at different stages of development (a very young plantation on a clearcut and a 35-year old forest), a vineyard, and several crop sites including bean, oil seed rape, triticale and irrigated maize, were measured during CERES, from 17 May to 26 15 June 2005.

\section{Material and methods}

The experiment took place in South-West France over ten ecosystems representative of the region (Table 1). The western part of the region is mostly composed of vineyards north, east and partly south of the city of Bordeaux, and south of Bordeaux, of Les Landes forest, part of which is being converted in cropland (moslty maize but also beans, carrots, etc.). The eastern part of the region is mostly characterised by agricultural lands with crop rotations composed of rapeseed, sunflower, maize, winter wheat, etc.
BGD

$6,2755-2784,2009$

\section{Effect of land use on carbon dioxide, water vapour and energy exchange}

N. Jarosz et al.

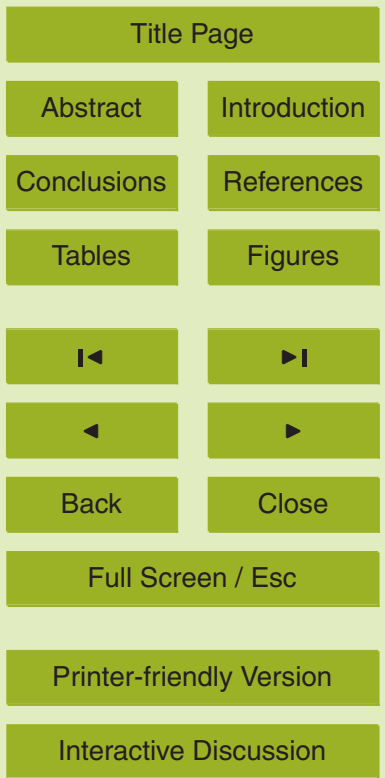




\subsection{Site characteristics}

BGD

\subsubsection{Forest sites}

Le Bray

The experimental site of Le Bray (LBR) is located in the Landes forest about $20 \mathrm{~km}$ 5 pine (Pinus pinaster Ait.) planted in 1970 and covering about 16 ha. Mean annual rainfall over the 1970-1999 period is $972 \mathrm{~mm}$ (Météo France, Mérignac, France). The trees are distributed in parallel rows along a northeast-southwest axis, with an inter-row spacing of $4 \mathrm{~m}$. In 2005 the canopy crown extended between 12 and $20 \mathrm{~m}$ above soil surface and stand density was about 390 trees ha $^{-1}$.

The understorey mostly consists of grass, mainly purple moor-grass (Molinia coerulea, L. Moench). The soil is a hydromorphic podzol with sand agglomerate at a depth of about $0.6 \mathrm{~m}$. It is covered by a litter formed by dead needles, dead grass, dead branches and decayed organic matter. A layer of compact sand, barely penetra15 ble by the roots, is located at a depth of about $0.8 \mathrm{~m}$. Inorganic sand lies below this layer.

A $38 \mathrm{~m}$ high instrumented tower is set up in the middle of the stand. The latter is surrounded by similar stands, except in the northwest direction where a clearcut was made at about $200 \mathrm{~m}$ from the tower following the December 1999 storm. This sector

Bilos

The site of Bilos (BIL) is located approximately $50 \mathrm{~km}$ southwest from Bordeaux in Les Landes forest. The stand is a very flat 60 ha clearcut maritime pine stand. Half of the site was sown in summer 2004 and the other half in summer 2005. The inter25
$6,2755-2784,2009$

\section{Effect of land use on carbon dioxide, water vapour and energy exchange}

N. Jarosz et al.

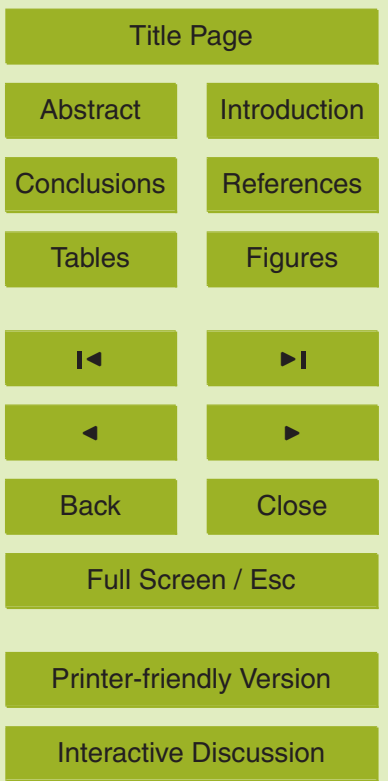


grasses (graminae), heather and gorse, with sparse fern. The soil is sandy podzol lying over a hard iron pan at $0.7 \mathrm{~m}$. A $6 \mathrm{~m}$ high mast is set up in the middle of the stand, which is bordered to the north by maize crops and mature maritime pine forest either.

\subsubsection{Crop sites}

5 Auradé

Auradé (AUR) plot is located on a hillside area near the Garonne river terraces (Table 1). The plot is characterised by a rapeseed-wheat-sunflower-wheat rotation. It was cultivated with rapeseed (Brassica napus L.) from 13 September 2004 to 27 June 2005. It was supplied with mineral fertilizer $\left(204 \mathrm{~kg} \mathrm{~N} \mathrm{ha}^{-1}\right.$ in total) and was not irrigated. Superficial tillages (5-10 cm depth on 4 July and 4 August) were done after rapeseed was harvested on 27 June to plough in residues, crop re-growth and weeds into the soil.

\section{Couhins}

The site of Couhins (COU) is a vineyard situated near Bordeaux (Table 1) in the Graves area named Pessac Leognan. The stand was about 6 ha, surrounded by vineyard, except to the south where some deciduous trees bordered the stand. Vineyard height was from 0.82 to $1.4 \mathrm{~m}$. The soil is composed of gravel outcrop on a argilo-calcareous hillside area.

\section{Cape Sud beans and maize}

The site of La Cape Sud is located $60 \mathrm{~km}$ south from Bordeaux (CSM for maize and

CSB for beans) in Les Landes region. The maize stand, of 87 ha in area, was surrounded by other maize crop stands except to the south where it was bordered by a $200 \mathrm{~m}$ strip of pine trees. A $4 \mathrm{~m}$ high mast was set up between two pivot-irrigation systems from the sowing at the end of April to the harvesting period on 27 September. Irrigation started on 29 May 2005. Another EC system was mounted at $2 \mathrm{~m}$ high on a

\section{0}

BGD

6, 2755-2784, 2009

Effect of land use on carbon dioxide, water vapour and energy exchange

N. Jarosz et al.

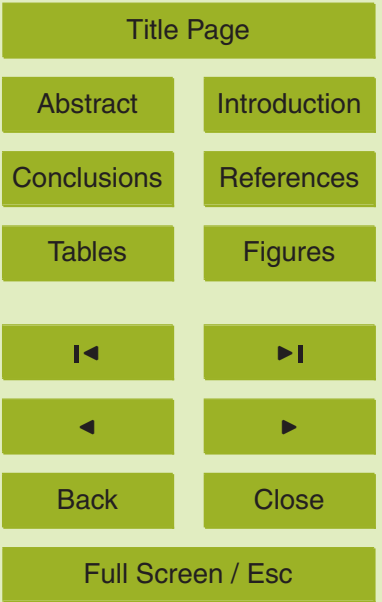

Printer-friendly Version

Interactive Discussion 
44 ha beans crop. Canopy heights were from 0.01 to $1.23 \mathrm{~m}$ and near zero to $0.25 \mathrm{~m}$ for maize and beans, respectively.

BGD

\section{Lamasquère}

Lamasquère (LAM) plot (Table 1) was cultivated with triticale (Triticosecale) from 24 5 November 2004 to 11 July 2005. It is part of an experimental farm owned by the "Ecole Supérieure d'Agronomie de Purpan" (ESAP). The instrumented site is boarding the Touch River and is characterised by a triticale-maize-wheat-maize rotation. The crop was fertilised with organic $\left(150 \mathrm{~kg} \mathrm{~N} \mathrm{ha}^{-1}\right)$ and mineral $\left(89 \mathrm{~kg} \mathrm{Nha}^{1}\right)$ fertilisers. To plough in residues and manure into the soil, the plot was superficially tilled before sowing (28 September 2004). Harvest occurred on 11 July 2005.

\section{Marmande}

Marmande site (MAR) was located $90 \mathrm{~km}$ south-east from Bordeaux. Maize was from $0.3 \mathrm{~m}$ to $1.4 \mathrm{~m}$ high during the CERES campaign and The plot was flat and irrigation was supplied out of the campaign period.

\subsection{Saint-Sardos}

Saint-Sardos site (SAR) was located about $50 \mathrm{~km}$ north-west from Toulouse. The plot was sown with maize, which was from near zero to $1.3 \mathrm{~m}$ high at the end of CERES. EC system was mounted in the middle of a 7.3 ha plot.

\subsubsection{Grassland site}

\section{SMOSREX (Le Fauga)}

SMOSREX is a long-term field experiment (2001-2008) conducted within the framework of the remote sensing SMOS (Soil Moisture and Ocean Salinity) mission prepa-
6, 2755-2784, 2009

\section{Effect of land use on carbon dioxide, water vapour and energy exchange}

N. Jarosz et al.

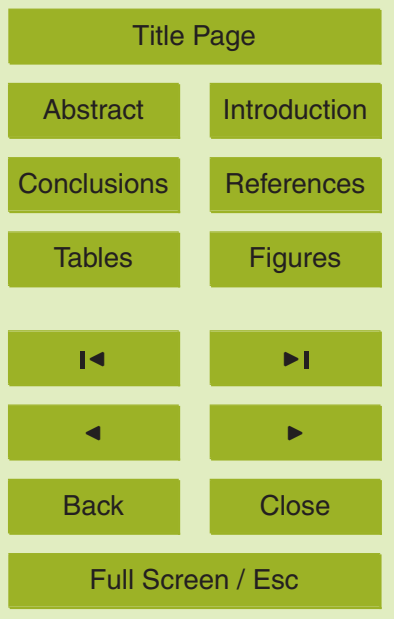

Printer-friendly Version

Interactive Discussion 
ration. It is located at the ONERA (Office National d'Etudes et de Recherches Aérospatiales) site named Le Fauga, about $30 \mathrm{~km}$ south of the city of Toulouse. It is a natural grass area kept as a fallow on a medium loamy textured soil. It is an experimental site for the observation of soil moisture observation, in-situ and remotely sensed. EC flux measurements have been measured since 2005.

\subsection{Meteorological measurements}

At all sites, except LBR, CSB and SAR net radiation $(\mathrm{Rn})$ was directly measured with a NrLite Pyrradiometer (Kipp \& Zonnen, Delft, The Netherlands). At LBR, net radiation is calculated from the balance between incoming and outgoing shortwave radiation

10 as measured by two CE180 pyranometer (Cimel Electronique, Paris, France) and incoming and outgoing longwave radiation as measured by a CG2 pyrgeometer (Kipp \& Zonnen, Delft, The Netherlands). At AUR, CSB, LAM and SAR incoming and outgoing shortwave and longwave radiations were also measured with a CNR1 (Kipp \& Zonen, Delft, The Netherlands). At BIL, LBR, COU and CSM, the global radiation 15 (Rg) was measured with a CE180 pyranometer (Cimel Electronique, Paris, France). Incoming and diffuse photosynthetically active radiation (PAR) were measured above the canopy using sunshine sensors BF2 or BF3 (Delta-T Devices, Cambridge, UK). At LBR, CSB, CSM and AUR, mean wind speed and direction were measured with a wind vane anemometer (5103 Young, Traverse City, Michigan, USA). A BIL and COU, 20 mean wind speed and direction were measured with a CE150 anemometer (Cimel Electronique, Paris, France) and wind direction with a WP200 wind vane (Campbell Scientific, Logan Utah, USA), respectively and at LAM with a 014A wind speed sensor and a 024A wind direction sensor (Met one instruments, inc., GrantsPass, OR, USA), respectively. Air temperature and relative humidity were measured with a HMP45 at 25 LBR, BIL, COU and CSM and a HMP35 at LAM and AUR (Vaisala, Helsinki, Finland). All these measurements were performed at $h_{\mathrm{EC}}$, as detailed in Table 1. Rainfall was measured with a rain gauge ARG100 (Campbell Scientific, Logan, USA) just above ground, except at LBR where the jauge was at $24 \mathrm{~m}$ high on another tower, just above

BGD

$6,2755-2784,2009$

Effect of land use on carbon dioxide, water vapour and energy exchange

N. Jarosz et al.

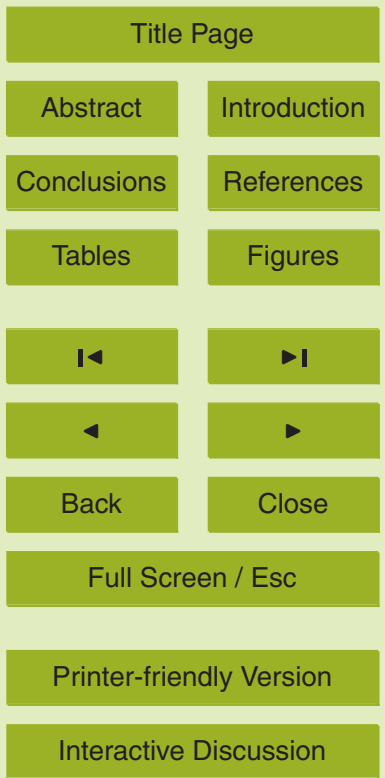


the top of the trees. Atmospheric pressure was measured at 2 and $1 \mathrm{~m}$ high at LBR and BIL, respectively, using a PTB101B Barometric Pressure Transmitter (Vaisala, Helsinki, Finland), at SAR and CSB at $0.3 \mathrm{~m}$ high using a PTB210 (Vaisala, Helsinki, Finland) and at AUR and LAM using a BS4 sensor (BS4, Delta-T, Cambridge, UK). Soil heat flux

5 (G) was measured using from two to five flux plates (Campbell scientific, Shepshed, UK or Hukseflux thermal sensors, Delft, The Netherlands) depending on the sites and corrected by an estimation taken from a two-step version of null-alignment method using soil temperature, water content and bulk density measurements between the soil surface and $1 \mathrm{~m}$ depth (Ogée et al., 2001). Soil water content (SWC) was measured at $10 \quad 0.05,0.23,0.34$ and $0.8 \mathrm{~m}$ depth using a Time-Domain Reflectometry (TDR) Trase (Soil Moisture Equipment Corp., Santa Barbara, CA) at three different locations at LBR and using Campbell CS615 or CS616 probes (Campbell Scientific, Logan Utah, USA) at AUR, BIL, CSM, COU and LAM. Soil bulk density was measured gravimetrically from samples collected at different depths and three locations in the vicinity of the other soil measurements. At CSB and SAR, SWC was measured using Theta probe ML2X (Delta-T devices, UK). Data were recorded every $10 \mathrm{~s}$ and averaged every half hour on CR10X, CR21X and CR23X Campbell data loggers (Campbell Scientific, Logan Utah, USA).

\subsection{Eddy-flux measurements}

20 The basic instruments and methods have been standardised throughout the Euroflux and following research programs (Grelle and Lindroth, 1996; Moncrieff et al., 1997; Aubinet et al., 2000; Baldocchi, 2003). The EC system consists of a 3-D sonic anemometer (Solent R2 or R3, Gill Instruments, Lymington, Hampshire, UK; CSAT 3, Campbell Scientific Inc, Logan, UT, USA or Young 81000V, R.M. Young Company, 25 Traverse City, Michigan, USA) coupled with an open path $\mathrm{CO}_{2} / \mathrm{H}_{2} \mathrm{O}$ InfraRed Gas Analyzer (IRGA) LI-7500 (LICOR, Lincoln, NE, USA) at all sites, except at CSB where a closed path IRGA LI-6262 was used. Instantaneous measurements of the three components of wind velocity, temperature $(T)$ and the molar fractions of $\mathrm{H}_{2} \mathrm{O}$ and $\mathrm{CO}_{2}$ were

BGD

6, 2755-2784, 2009

Effect of land use on carbon dioxide, water vapour and energy exchange

N. Jarosz et al.

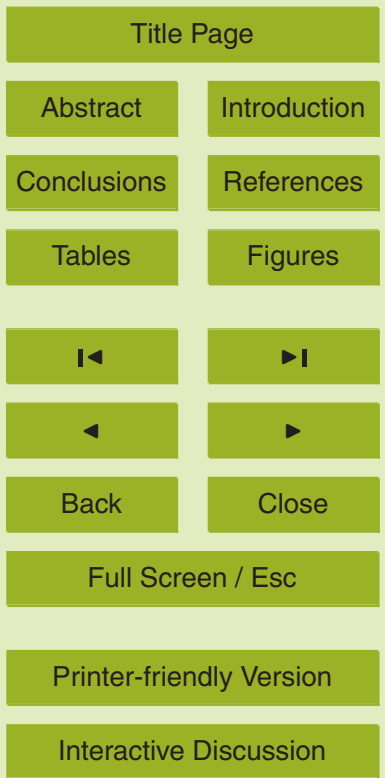


collected and stored at $20.8 \mathrm{~Hz}$ at LBR site (Solent R2) and at $20 \mathrm{~Hz}$ at the other sites (Campbell Csat3, Solent R3 or Young 81000V). Turbulent scalar eddy fluxes were then calculated for each half hour as the covariance between the vertical wind speed and the scalar $\left(\mathrm{CO}_{2}, \mathrm{H}_{2} \mathrm{O}, T\right)$.

$5 \quad$ All flux data were computed and corrected as recommended by Aubinet et al. (2000) using the method described in Béziat et al. (2008): coordin ate axes were rotated so that mean vertical velocity was zero except at LBR (tall pine forest) where a Planar fit method were applied; water vapour fluxes were corrected for the effect of density fluctuations (Webb et al., 1980) and, all fluxes were corrected for high frequency losses 10 using Moore approach (Moore et al., 1986). Finally, all half-hourly values of fluxes that were missing or did not meet with quality criteria, were gap-filled using the method of Reichstein et al. (2005).

As can be seen in Table 2, the energy balance, the partitioning of net radiation into sensible heat flux, $H$, latent heat flux, $L E$, soil heat flux, $G$, and canopy heat storage, $S$, 15 closes satisfactory within the $95 \%$ confidence level at all sites, from 75 to $92 \%$, except at SAR (55\%). For the latter, this incomplete energy balance closure is due to measurement failure of soil heat flux with flux plates. Otherwise, the energy imbalance is within the range of about 5 to $30 \%$, typically found in experimental studies that measure directly the different components of the energy balance (Aubinet et al., 2000; Wilson et al., 2002).

\subsection{Plant measurements}

Leaf area index (LAl), biomass and canopy height were measured in order to follow the growth of crops and herbaceous layer in forest between May and July. They were estimated at least twice a month. The LAI of herbaceous layers and biomass were measurements. The LAl of the trees were predicted using the model of Granier and Loustau (1994).

BGD

$6,2755-2784,2009$

Effect of land use on carbon dioxide, water vapour and energy exchange

N. Jarosz et al.

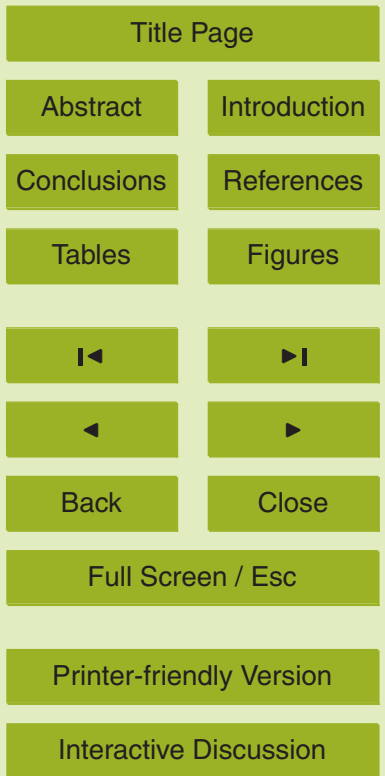




\section{Results and discussion}

\subsection{Meteorological conditions and plant development}

Eddy fluxes were measured over the ten different canopies from 17 May to 26 June 2005. Globally, the sites have similar climates. However some variability in meteoro5 logical conditions may occur across the different sites.

During the experiment, the weather was particularly hot and dry. Total precipitation ranged between $8-14 \mathrm{~mm}$ and $31-54 \mathrm{~mm}$ from the west to the east (Fig. 1). During the experiment, the weather was particularly hot and dry. Air temperature did not differ significantly among ecosystems, but the western part of the region was slightly warmer than the eastern part. Temperatures were particularly hot with mean daily values from $14.2^{\circ} \mathrm{C}$ at the beginning of the experiment to $25.2^{\circ} \mathrm{C}$ at the end. Maximum temperatures ranged from $25.5^{\circ} \mathrm{C}$ at CSM to $28.6^{\circ} \mathrm{C}$ at LBR and BIL, the lower values being due to irrigation. On the hottest days, half hourly nocturnal temperatures did not decrease below $20^{\circ} \mathrm{C}$ (not shown). Maximum PAR occurred when VPD was maximum. PAR did not differ markedly among sites, except for some decrease due to local rain events. As expected with irrigation, the CSM site exhibited the highest soil water content (unfortunately, SWC is not available at the other irrigated sites). As the air became drier, the soil water content decreased throughout the CERES campaign for the pine stands (LBR and BIL) and the winter crops (AUR and LAM) and decreased smoothly for the vineyard (COU). Furthermore, the forest and vineyard sites experienced a water stress due to high soil water deficit from mid-June onwards. Soil moisture was higher at sites where LAI became close to zero (Fig. 2) and transpiration ceased (AUR and LAM). This difference in soil moisture may also be due to the loamy and clay soil texture compared to the sandy soil (LBR and BIL) where water is expected to percolate more easily.

25 As expected, during the experimental period, the herbaceous biomass and LAI of summer crops (CSM, MAR, SAR, CSB) show sheer increase (Fig. 2) from 0.1 (CSB) to $0.4 \mathrm{~kg} \mathrm{DM} \mathrm{m}^{-2}$ (MAR) and from $2 \mathrm{~m}^{2} \mathrm{~m}^{-2}$ (CSB) to more than $4 \mathrm{~m}^{2} \mathrm{~m}^{-2}$ (MAR), respectively, and reach the highest values. The winter crops (AUR, LAM) have their

Effect of land use on carbon dioxide, water vapour and energy exchange

N. Jarosz et al.

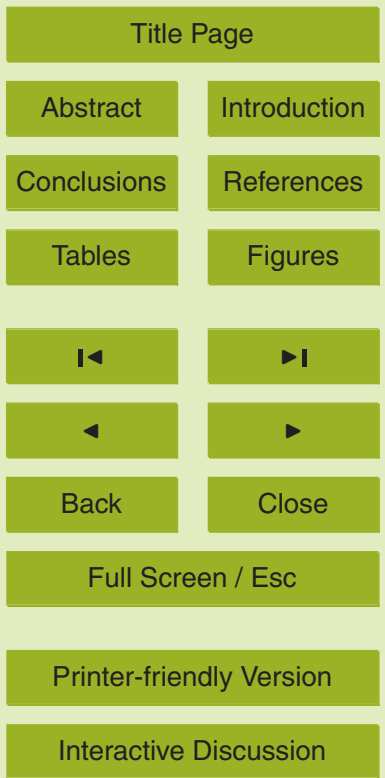

2765 
maximum LAI and leave biomass before senescence starts, just a few days after the beginning of the campaign. LAI values show a sharp decrease after senescence but total biomass remains high before harvest due to reallocation from leaves and stems to fruits (Béziat et al., 2008). At FAU, the biomass is between 0.4 to $0.6 \mathrm{~kg} \mathrm{DM} \mathrm{m}^{-2}$ 5 and the LAl decreases continuously from 2.2 to $0.3 \mathrm{~m}^{2} \mathrm{~m}^{-2}$. The same explanation as for winter crops is suitable as the main species that composed the grassland is a graminae. Comparatively, the other ecosystems (LBR, BIL, COU) have a much slower growth emphasized by soil water deficit at forest sites.

\subsection{Effect of land use on water and energy fluxes}

10 Although incident radiation is very similar between sites, the ten ecosystems show different partitioning of available energy. Net radiation is the highest above the maritime pine forest, followed, in decreasing order, by the crops, the vineyard and the grassland (Table 3). Over the whole campaign period, the Bowen ratio $(\beta=H / L E)$ is larger than 1 at forest sites, almost 1 at vineyard site and less than 1 otherwise.

15 At LBR, $\beta$ is almost equal to 1 at the beginning of the campaign and as the weather becomes drier, most of net radiation dissipates as sensible heat, transpiration of the needles shutting down due to water stress inducing stomatal closure. This is in agreement with Jarosz et al. (2008) and Baldocchi et al. (2000) who found a large increase in $\beta$ as the surface was drying at the same site in 2002 and in a ponderosa pine forest, 20 respectively.

In winter crops and on grassland sites, most of the net radiation is dissipated as latent heat fluxes during the first half of the campaign, when water does not limit evaporation and as sensible heat during the rest of the period, when the LAI decreases and the soil dries out, less water becoming available for transpiration. Conversely, in summer

crops, latent heat fluxes increase and sensible heat fluxes decrease with increasing LAI and irrigation, leading to $\beta$ values almost equal to 1 at the beginning of the campaign and less than 1 afterwards. Lower Rn values over the maize canopies before the growth starts can be explained by greater shortwave and longwave energy losses

\section{6}

BGD

$6,2755-2784,2009$

Effect of land use on carbon dioxide, water vapour and energy exchange

N. Jarosz et al.

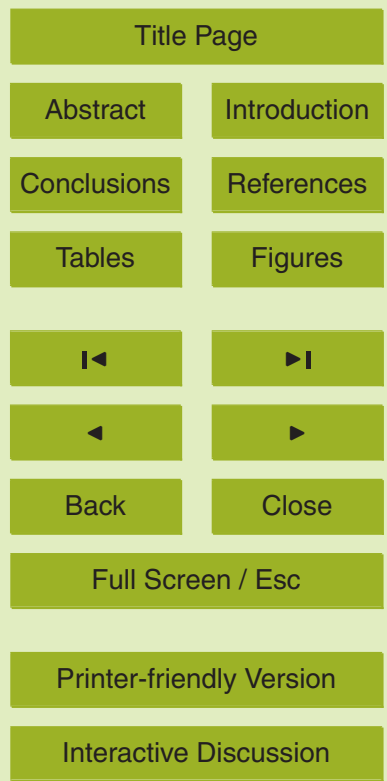


due to the albedo of sand (CSM, CSB) which is much larger compared to vegetation (Monteith and Unsworth, 1990). Moreover, having more exposed soil, young canopies will experience losses of incoming shortwave radiation. At $\mathrm{COU}, \beta$ is slightly more than 1 ; the grass in the interrows transpires during the first half of the period when the vine 5 LAl is low, only then the transpiration of vine leaves takes over during the second half while the grass is drying.

In the clearcut, absorbed solar energy increases the surface temperature, leading to an important loss of sensible heat and especially infrared radiation, thus reducing net radiation by 20 and $35 \%$ compared to winter crops and the forest, respectively. These 10 latter ecosystems maintain a cooler surface using more energy for evaporation and canopy transpiration. As already shown from clearcut and forest studies (Kowalski et al., 2003), the shift from forest to crops reinforce the expectation that tree harvesting and logging operations (clearcutting in plantation forestry) tend to increase heat fluxes and thus Bowen ratio (Schulze et al., 1999). Moreover, soil warming is induced by the 15 removal of canopy shade.

Converting a mature forest to a clearcut or bare soil available to agricultural use enhances the sensible heat flux. However, as the bare soil shifts to a maize crop, the sensible heat flux clearly decreases within the first month after seedling as the vegetation grows and moreover as the irrigation is operating. In Les Landes part of 20 the region, the maritime pine forest dominates the land cover. However, progressively more forest is converted to crops, mainly irrigated maize. Knowing that crop lands are left as bare soil in winter, it is likely that converting forest to agricultural sites will enhance sensible heat fluxes at a yearly scale.

\subsection{Effect of land use on $\mathrm{CO}_{2}$ fluxes}

25 The various vegetation types show contrasting net ecosystem exchange (NEE) dynamics following their growth status and respective behaviour in response to drought.

Forests (mature pines and clearcut) photosynthesis is larger than respiration during the day. The mean rate of $\mathrm{CO}_{2}$ fluxes reaches $-16 \mu \mathrm{mol} \mathrm{m}^{-2} \mathrm{~s}^{-1}$ for pines and

\section{7}

\section{BGD}

$6,2755-2784,2009$

\section{Effect of land use on carbon dioxide, water vapour and energy exchange}

N. Jarosz et al.

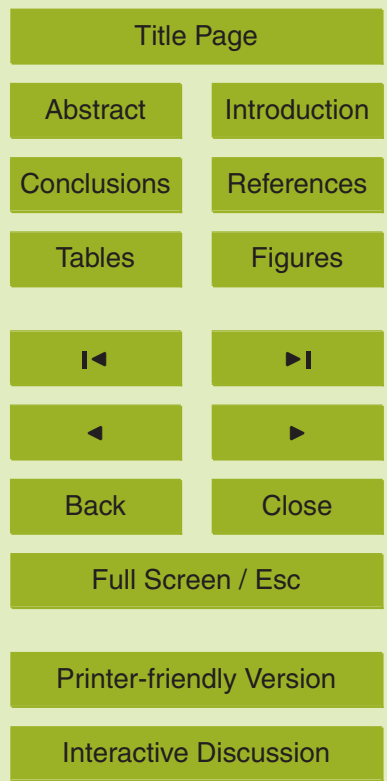


$-2 \mu \mathrm{mol} \mathrm{m}{ }^{-2} \mathrm{~s}^{-1}$ for grasses. During week 5 and $6, \mathrm{CO}_{2}$ uptake decreases by one third for pines and by half for the clearcut, which is well connected to lower vegetation transpiration (Fig. 3). Both regulate water loss by stomatal closure which induces less $\mathrm{CO}_{2}$ uptake when the weather is particularly dry. The understorey vegetation of the 5 maritime pine forest is dominated by the purple moor-grass, Molinia coerulea, while vegetation that composed the clearcut is a mix of grasses (graminae), heather and gorse (Kowalski et al., 2003). Therefore, conversely to the purple moor-grass, the clearcut vegetation seems to be as sensitive to drought as the pine trees, whereas the purple moor-grass alone does not express any significant stomatal control (Jarosz et 10 al., 2008). At COU, the mean rates of NEE varied from -4 to $-7 \mu \mathrm{mol} \mathrm{m}^{-2} \mathrm{~s}^{-1}$, higher values being observed during the drier period when the LAI is higher. The vineyard has access to deep soil water reserve and hence has an almost linear carbon fixation rate throughout the season (Fig. 4a).

Winter crops and grassland have similar behaviour throughout the campaign 15 (Fig. 4b). According to their decreasing LAI, maximum NEE fluxes decrease almost gradually from -27 to $4 \mu \mathrm{mol} \mathrm{m}{ }^{-2} \mathrm{~s}^{-1}$, from -24 to $-2 \mu \mathrm{mol} \mathrm{m} \mathrm{m}^{-2} \mathrm{~s}^{-1}$ and from -18 to $-1 \mu \mathrm{mol} \mathrm{m}{ }^{-2} \mathrm{~s}^{-1}$ for triticale, oil seed rape and grassland, respectively. At AUR, although the leaves dry out, carbon uptake is still high until harvesting, due to oil seed rape stems photosynthesis (Béziat et al., 2008). Figure 4e shows the senescence of 20 the plant resulting in respiration larger than assimilation. Summer crops are sources of carbon at the beginning of the campaign and as LAI increases (Fig. 4c), the crops become carbon sinks with maximum NEE values from -16 (CSB) to $-42 \mu \mathrm{mol} \mathrm{m}^{-2} \mathrm{~s}^{-1}$ (MAR). Maize crops at MAR and CSM and the bean crop at CSB exhibit the same growth trend at a rate of about $17 \%$. At SAR, the maize crop has a different pattern certainly due to the use of a different cultivar than on the other sites as well as different soil properties. Moreover, canopy growth occurs while the weather conditions are dry and irrigation is not yet operating. These NEE values are in agreement with other studies showing larger values of NEE for $\mathrm{C}_{4}$ plants (Pattey et al., 2002; Hollinger et al., 2005) than for $C_{3}$ plants (Baldocchi, 1994; Soegaard et al., 2003; Anthoni et al., 2004;

\section{Effect of land use on carbon dioxide, water vapour and energy exchange}

N. Jarosz et al.

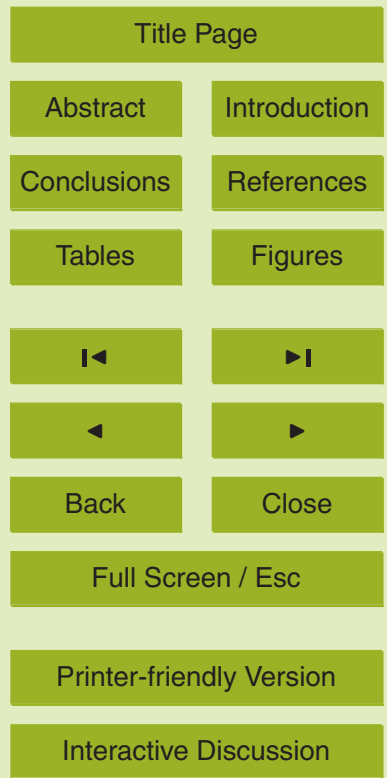


Moureaux et al., 2006).

These $\mathrm{CO}_{2}$ fluxes results in different carbon budgets during the CERES campaign. Both the clearcut (Fig. 4d) and summer crops before irrigation and plant growth (Fig. 4f) behave as sources of $\mathrm{CO}_{2}$, whereas the vineyard, the mature forest (Fig. $4 \mathrm{~d}$ ) and winter 5 crops (Fig. 4e) act as sinks. However the maize crops become substantial sinks of $\mathrm{CO}_{2}$ after the start of irrigation and canopy growth, with fluxes twice as large as for the 35-year old forest. Finally, forest, grassland and crops have sequestrated from about $50 \mathrm{gC} \mathrm{m}^{-2}$ (COU) to $230 \mathrm{gC} \mathrm{m}^{-2}$ (MAR), while BIL and CSB have rejected about $30 \mathrm{gC} \mathrm{m}^{-2}$.

10 These results support the idea that harvest converts mature forest carbon sinks into carbon sources, whether the forest is converted in bare soil (Kowalski et al., 2003) or agricultural fields. However, the choice of the crop rotation and management practises may shift an agroecosystem from a source to a nearly carbon neutral or a carbon sink (Verma et al., 2005; Aubinet et al., 2009; Béziat et al., 2008).

\subsection{Potential impacts of land cover change on WUE}

To further investigate the response of the different ecosystems, we examined the water use efficiency (WUE), which represents the ability of the canopy to assimilate carbon while limiting water loss. WUE can be defined as the regression slope between the net $\mathrm{CO}_{2}(F C)$ and water vapour $(E)$ fluxes (Baldocchi, 1994). Canopies in contrasting ecosystems have different WUE because of inherent physiological variation in leaf gas exchange characteristics and differences in environmental conditions among habitats (Farquhar et al., 1989).

Table 4 shows how well carbon and water fluxes are coupled for the various functional groups. We observe that during the CERES period, winter crops, irrigated summer crops, grassland and forest use water more efficiently than the other summer crops and the clearcut forest. WUE values were from 7.5 to $9.9 \mathrm{mg} \mathrm{g}^{-1}$, from 10.3 to $12.6 \mathrm{mg} \mathrm{g}^{-1}$, and $9.1 \mathrm{mg} \mathrm{g}^{-1}$ for winter crops and grassland, irrigated maize and forest ecosystem, respectively. Lower values ranged between 3.9 and $5.2 \mathrm{mg} \mathrm{g}^{-1}$ at the

BGD

6, 2755-2784, 2009

Effect of land use on carbon dioxide, water vapour and energy exchange

N. Jarosz et al.

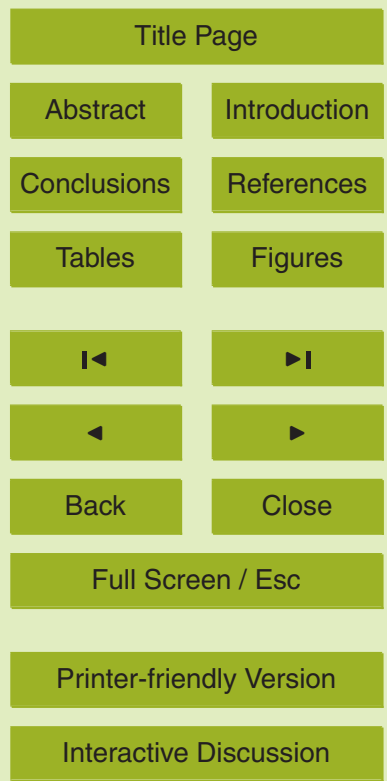


other sites. Besides, variations in water vapour fluxes explain more of the variance in $\mathrm{CO}_{2}$ exchange of winter crops, forests and grassland than it does for summer crops. The coefficients of variation were from 0.25 to 0.71 . Hence, the higher the ecosystem carbon uptake, the higher the water use.

$5 \quad$ WUE is a function of leaf intercellular $\mathrm{CO}_{2}$ concentration $\left(\mathrm{C}_{i}\right)$ that is higher for $\mathrm{C}_{3}$ than $\mathrm{C}_{4}$ leaves and hence lower WUE is expected for $\mathrm{C}_{3}$ leaves under similar environmental conditions but Baldocchi (1994) evidenced that maize and wheat crops which were not suffering from water deficit showed similar WUE of about $11 \mathrm{mg} \mathrm{g}^{-1}$. These values are in the range of values obtained from irrigated maize at CSM and MAR. However, 10 on the maize site without irrigation and with low LAI (SAR), WUE is lower. Therefore, maize WUE appears to be the more efficient in terms of water but with consistent water supply, particularly in Les Landes region where water was provided in excess to plant transpiration and soil evaporation (Table 3). As for triticale, which is close to wheat, WUE shows lower value in our study than in Baldocchi et al. (1994) because 15 the considered period is not the same. In the latter study, wheat was green while in our study senescence started during the campaign.

At LBR, the WUE value is close to that found in an earlier study in water-stressed conditions. Indeed, Lamaud et al. (1996) reported values between 6.4 and $9.1 \mathrm{mg} \mathrm{g}^{-1}$ during summer 1994 and 1995, respectively, corresponding to well-watered and waterstressed conditions, respectively. This result meets with that of Picon et al. (1996) who performed leaf-scale measurements on a maritime pine and sessile oak forest. They found that in response to water stress, maritime pines presented higher values of WUE, a drought-avoiding strategy. Indeed, species using drought-avoidance mechanisms prevent damage by early stomatal closure before any change in leaf water status occurs, whereas drought-tolerant species exhibit simultaneous decreases in stomatal conductance and water potential.

Finally, at sites where the vegetation is well developped, the slopes between $\mathrm{CO}_{2}$ fluxes and evapotranspiration show a strong linkage between carbon gain and water loss.

\section{BGD}

$6,2755-2784,2009$

\section{Effect of land use on carbon dioxide, water vapour and energy exchange}

N. Jarosz et al.

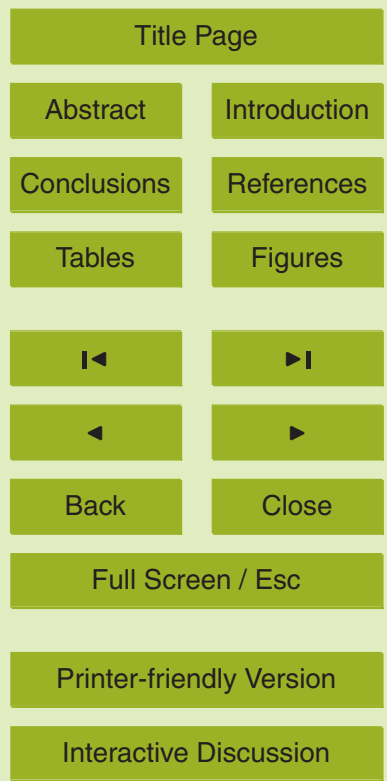




\section{Summary - conclusions}

This study shows mass and energy fluxes over ten different ecosystems in the same region and the same period of time during the CERES experiment. Ecosystem types are highly specific in the magnitude and dynamics of the energy and mass flux exchange 5 with the atmosphere.

The different partitioning of available energy within the different ecosystems show that converting a mature forest to a clearcut or bare soil available for agricultural use enhances the sensible heat flux. However, as the bare soil is covered by vegetation and irrigation starts, the sensible heat flux clearly decreases.

The various vegetation types also show contrasting net ecosystem exchange (NEE) dynamics following their growth status and respective behaviour in response to drought. This results in different carbon budgets during the CERES campaign. Both the clearcut and summer crops before irrigation and plant growth behave as sources of $\mathrm{CO}_{2}$, whereas the vineyard, the mature forest and winter crops act as sinks. However the maize crops become substantial sinks of $\mathrm{CO}_{2}$ after the start of irrigation and canopy growth, with fluxes twice as large as for the pine forest. We also observe that during the CERES period, winter crops, irrigated summer crops, grassland and forests use water more efficiently than the other summer crops and the clearcut forest.

This collected data provides a good basis for a comparative study of the main ecosystems of the region, and for up-scaling fluxes at the regional level, in conjunction with all other measurements performed during the 2005 CERES experiment.

Acknowledgements. Many thanks to M. Irvine, D. Garrigou, R. Burlett and S. Debesa from INRA for technical assistance. The CarboEurope-IP project supported this work.

BGD

$6,2755-2784,2009$

Effect of land use on carbon dioxide, water vapour and energy exchange

N. Jarosz et al.

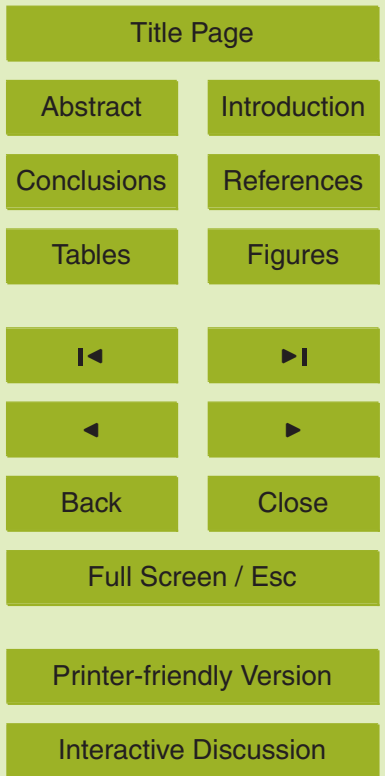


The publication of this article is financed by CNRS-INSU.

\section{References}

Anthoni, P. M., Freibauer, A., Kolle, O., and Schulze, E.-D.: Winter wheat carbon exchange in Thuringia, Germany, Agr. Forest Meteorol., 121, 55-67, 2004.

Aubinet, M., Moureaux, C., Bodson, B., Dufranne, D., Heinesch, B., Suleau, M., Vancutsem, F., and Vilret, A.: Carbon sequestration by a crop over a 4-year sugar beet/winter wheat/seed potato/winter wheat rotation cycle, Agr. Forest Meteorol., 149, 407-418, 2009.

Aubinet, M., Grelle, A., Ibrom, A., Rannik, U., Moncrieff, J., Foken, T., Kowalski, A. S., Martin, P. H., Berbigier, P., Bernhofer, C., Clement, R., Elbers, J., Granier, A., Grünwald, T., Morgenstern, K., Pilegaard, K., Rebmann, C., Snijders, W., Valentini, R., and Vesala, T.: Estimates of the annual net carbon and water exchange of forests: the EUROFLUX methodology, Adv. Ecol. Res., 30, 113-175, 2000.

Aubinet, M., Chermanne, B., Vandenhaute, M., Longdoz, B., Yernaux, M., and Laitat, E.: Long term carbon dioxide exchange above a mixed forest in the Belgian Ardennes, Agr. Forest Meteorol., 108, 293-315, 2001.

Baldocchi, D.: A comparative study of mass and energy exchange rates over a closed $\mathrm{C} 3$ (wheat) and an open C4 (corn) crop: II. $\mathrm{CO}_{2}$ exchange and water use efficiency, Agr. Forest Meteorol., 67, 291-321, 1994.

20 Baldocchi, D. D., Law, B. E., and Anthoni, P. M.: On measuring and modeling energy fluxes above the floor of a homogeneous and heterogeneous conifer forest, Agr. Forest Meteorol., 102, 187-206, 2000.

Baldocchi, D. D., Falge, E., Gu, L., Olson, R., Hollinger, D., Running, S., Anthoni, P., Bernhofer, C., Davis, K., Fuentes, J., Goldstein, A., Katul, G., Law, B., Lee, X., Malhi, Y., Meyers, T.,

\section{Effect of land use on carbon dioxide, water vapour and energy exchange}

N. Jarosz et al.

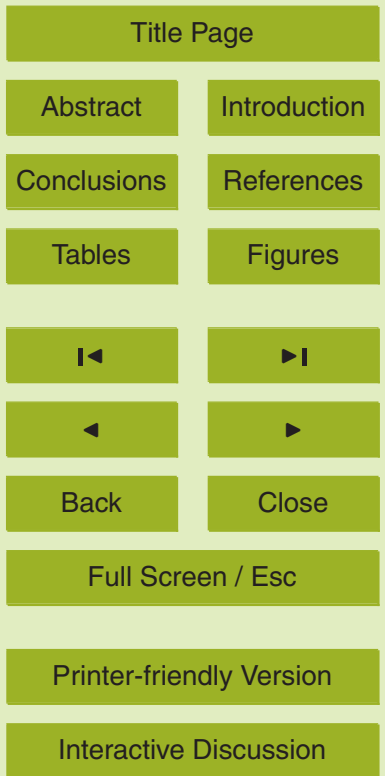


Wilson, K., and Wofsy, S.: FLUXNET: a new tool to study the temporal and spatial variability of ecosystem-scale carbon dioxide, water vapor and energy flux densities, B. Am. Meteorol. Soc., 82, 2415-2434, 2001.

Baldocchi, D. D.: Assessing the eddy covariance technique for evaluating carbon dioxide exchange rates of ecosystems: past, present and future, Glob. Change Biol., 9, 479-492, 2003.

Berbigier, P., Bonnefond, J. M., and Mellmann, P.: $\mathrm{CO}_{2}$ and water vapour fluxes for 2 years above Euroflux forest site, Agricultural and Forest Meteorology, 108, 183-197, 2001.

Béziat, P., Ceschia, E., and Dedieu, G.: Carbon balance of a three crop succession over two cropland sites in South-West France, Agr. Forest Meteorol., submitted, 2008.

Dolman, A. J., Noilhan, J., Durand, P., Sarrat, C., Brut, A., Piguet, B., Butet, A., Jarosz, N., Brunet, Y., Loustau, D., Lamaud, E., Tolk, L., Ronda, R., Miglietta, F., Gioli, B., Magliulo, E., Esposito, M., Gerbig, C., Körner, S., Galdemard, P., Ramonet, M., Ciais, P., Neininger, B., Hutjes, R. W. A., Elbers, J. A., Macatangay, R., Schrems, O., Pérez-Landa, G., Sanz, M. J., Scholz, Y., Facon, G., Ceschia, E., and Beziat, P.: The CarboEurope Regional Experiment Strategy, B. Am. Meteorol. Soc., 87, 1367-1379, 2006.

Farquhar, G. D., Ehleringer, J. R., and Hubick, K. T.: Carbon Isotope Discrimination and Photosynthesis, Annu. Rev. Plant. Phys., 40, 503-537, 1989.

Goulden, M. L., Wofsy, S. C., Harden, J. W., Trumbore, S. E., Crill, P. M., Gower, S. T., Fries, T., Daube, B. C., Fan, S.-M., Sutton, D. J., Bazzaz, A., and Munger, J. W.: Sensitivity of boreal forest carbon balance to soil thaw, Science, 279, 214-217, 1998.

Granier, A. and Loustau, D.: Measuring and modelling the transpiration of a maritime pine canopy from sap-flow data, Agr. Forest Meteorol., 71, 61-81, 1994.

Granier, A., Ceschia, E., Damesin, C., Dufrêne, E., Epron, D., Gross, P., Lebaube, S., Le 25 Dantec, V., Le Goff, N., Lemoine, D., Lucot, E., Ottorini, J. M., Pontailler, J. Y., and Saugier, B.: The carbon balance of a young Beech forest, Funct. Ecol., 14, 312-325, 2000.

Grelle, A. and Lindroth, A.: Eddy-correlation system for long-term monitoring of fluxes of heat, water vapour and $\mathrm{CO}_{2}$, Glob. Change Biol., 2, 297-307, 1996.

Halldin, S., Bergström, H., Gustafsson, D., Dahlgren, L., Hjelm, P., Lundin, L.-C., Mellander, P.E., Nord, T., Jansson, P.-E., Seibert, J., Stähli, M., Szilagyi Kishné, A., and Smedman, A.-S.: Continuous long-term measurements of soil-plant-atmosphere variables at an agricultural site, Agr. Forest Meteorol., 98-99, 75-102, 1999.

Hollinger, S. E., Bernacchi, C. J., and Meyers, T. P.: Carbon budget of mature no-till ecosystem

\section{Effect of land use on carbon dioxide, water vapour and energy exchange}

N. Jarosz et al.

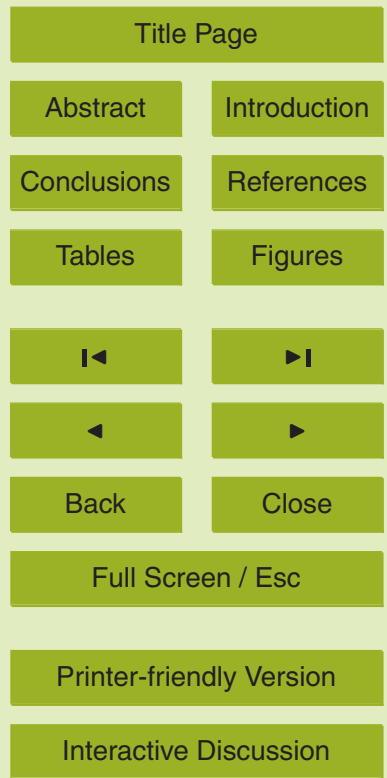


in north central regions of the United States, Agr. Forest Meteorol., 130, 59-69, 2005.

Houghton, R. A.: Revised estimates of the annual net flux of carbon to the atmosphere from changes in land use and land management 1850-2000, Tellus B, 55, 378-390, 2003.

Hutchinson, J. J., Campbell, C. A., and Desjardins, R. L.: Some perspectives on carbon sequestration in agriculture, Agr. Forest Meteorol., 142, 288-302, 2007.

Jarosz, N., Brunet, Y., Lamaud, E., Irvine, M., Bonnefond, J.-M., and Loustau, D.: Carbon dioxide and energy flux partitioning between the understorey and the overstorey of a maritime pine forest during a year with reduced soil availability, Agr. Forest Meteorol., 148, 1508-1523, 2008.

10 Kalnay, E. and Cai, M.: Impact of urbanization and land-use change on climate, Nature, 423, 528-531, 2003.

Kowalski, A., Sartore, M., Burlett, R., Berbigier, P., and Loustau, D.: The annual carbon budget of a French pine forest (Pinus pinaster) following harvest, Glob. Change Biol., 9, 1051-1065, 2003.

Lamaud, E., Brunet, Y., and Berbigier, P.: Radiation and water use efficiencies of two coniferous forest canopies, Phys. Chem. Earth, 21, 361-365, 1996.

Lindroth, A., Grelle, A., and Moren, A. S.: Long-term measurements of boreal forest carbon balance reveal large temperature sensitivity, Glob. Change Biol., 4, 443-450, 1998.

Moncrieff, J., Massheder, J. M., de Bruin, H., Elbers, J., Friborg, J., Heusinkveld, T., Kabat, P., Scott, P., Soegaard, H., and Verhoef, A.: A system to measure surface fluxes of momentum, sensible heat, water vapour and carbon dioxide, Journal of Hydrobiology, 188/189, 589-611, 1997.

Monteith, J. L. and Unsworth, M.: Principles of environmental physics, 2nd Ed., 291 pp., 1990.

Moore, C. J.: Frequency response corrections for eddy correlation systems, Bound.-Lay. Meteorol., 37, 17-35, 1986.

Moureaux, C., Debacq, A., Bodson, B., Heinesch, B., and Aubinet, M.: Annual net ecosystem carbon exchange by a sugar beet crop, Agr. Forest Meteorol., 139, 25-39, 2006.

Ogée, J., Lamaud, E., Brunet, Y., Berbigier, P., and Bonnefond, J. M.: A long-term study of soil heat flux under a forest canopy, Agr. Forest Meteorol., 106, 173-186, 2001.

30 Pattey, E., Strachan, I. B., Desjardins, R. L., and Massheder, J. M.: Measuring nighttime $\mathrm{CO}_{2}$ flux over terrestrial ecosystems using eddy covariance and noctural boundary layer methods, Agr. Forest Meteorol., 113, 145-158, 2002.

Picon, C., Guehl, J.-M., and Ferhi, A.: Leaf gas exchange and carbon isotope composition
BGD

6, 2755-2784, 2009

Effect of land use on carbon dioxide, water vapour and energy exchange

N. Jarosz et al.

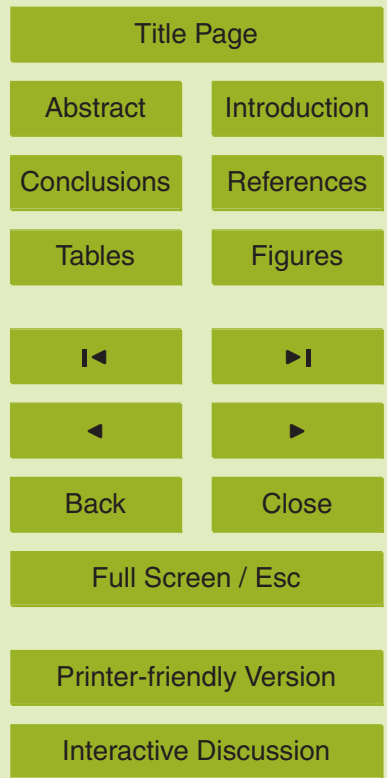


responses to drought in a drought-avoiding (Pinus pinaster) and a drought-tolerant (Quercus petraea) species under present and elevated atmospheric $\mathrm{CO}_{2}$ concentrations, Plant Cell Environ., 19, 182-190, 1996.

Pielke Sr., R. A.: Land Use and Climate Change, Science, 310, 1625-1626, 2005.

5 Pilegaard, K., Hummelshoj, P., Jensen, N. O., and Chen, Z.: Two years of continuous $\mathrm{CO}_{2}$ eddy-flux measurements over a Danish beech forest, Agr. Forest Meteorol., 107, 29-41, 2001.

Reichstein, M., Falge, E., Baldocchi, D., Papale, D., Aubinet, M., Berbigier, P., Bernhofer, C., Buchmann, N., Gilmanov, T., Granier, A., Grünwald, T., Havránková, K., Ilvesniemi, H., Janous, D., Knohl, A., Laurila, T., Lohila, A., Loustau, D., Matteucci, G., Meyers, T., Miglietta, F., Ourcival, J. M., Pumpanen, J., Rambal, S., Rotenberg, E., Sanz, M., Tenhunen, J., Seufert, G., Vaccari, F., Vesala, T., Yakir, D., and Valentini, R.: On the separation of net ecosystem exchange into assimilation and ecosystem respiration: review and improved algorithm, Glob. Change Biol., 11, 1424-1439, 2005.

Schulze, E. D., Lloyd, J., Kelliher, F. M., Wirth, C., Rebmann, C., Lühker, B., Mund, M., Knohl, A., Milyukova, I. M., Schulze, W., Ziegler, W., Varlagin, A. B., Sogachev, A. F., Valentini, R., Dore, S., Grigoriev, S., Kolle, O., Panfyorov, M. I., Tchebakova, N., and Vygodskaya, N. N.: Productivity of forests in the Eurosiberian boreal region and their potential to act as a carbon sink - a synthesis, Glob. Change Biol., 5, 703-722, 1999.

Seguin, B., Arrouays, D., Balesdent, J., Soussana, J.-F., Bondeau, A., Smith, P., Zaehle, S., de Noblet, N., and Viovy, N.: Moderating the impact of agriculture on climate, Agr. Forest Meteorol., 142, 278-287, 2007.

Sellers, P. J., Hall, F. G., Kelly, R. D., Black, A., Baldocchi, D., Berry, J., Ryan, M., Ranson, K. J., Crill, P. M., Lettenmaier, D. P., Margolis, H., Cihlar, J., Newcomer, J., Fitzjarrald, D., Jarvis, P. G., Gower, S. T., Halliwell, D., Williams, D., Goodison, B., Wickland, D. E., and Guertin, F. E.: BOREAS in 1997: Experiment overview, scientific results, and future directions, J. Geophys. Res., 102(D24), 28731-28770, 1997.

Smith, P., Andrén, O., Karlsson, T., Perälä, P., Regina, K., Rounsevell, M., and Van Wesemael, B.: Carbon sequestration potential in European croplands has been overestimated, Glob. $30 \quad$ Change Biol., 11, 2153-2163, 2005.

Soegaard, H., Jensen, N. O., Boegh, E., Hasager, C. B., Schelde, K., and Thomsen, A.: Carbon dioxide exchange over agricultural landscape using eddy correlation and footprint modelling, Agr. Forest Meteorol., 114, 153-173, 2003.

\section{BGD}

6, 2755-2784, 2009

\section{Effect of land use on carbon dioxide, water vapour and energy exchange}

N. Jarosz et al.

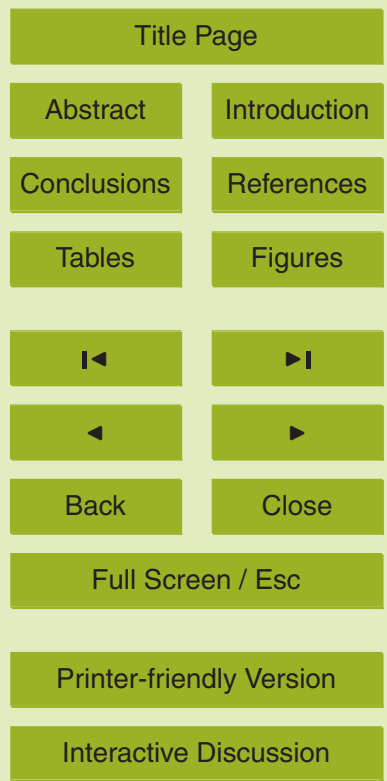


Soussana, J. F., Allard, V., Pilegaard, K., Ambus, P., Amman, C., Campbell, C., Ceschia, E., Clifton-Brown, J., Czobel, S., Domingues, R., Flechard, C., Fuhrer, J., Hensen, A., Horvath, L., Jones, M., Kasper, G., Martin, C., Nagy, Z., Neftel, A., Raschi, A., Baronti, S., Rees, R. M., Skiba, U., Stefani, P., Manca, G., Sutton, M., Tuba, Z., and Valentini, R.: Full accounting of the greenhouse gas $\left(\mathrm{CO}_{2}, \mathrm{~N}_{2} \mathrm{O}, \mathrm{CH}_{4}\right)$ budget of nine European grassland sites, Agr. Ecosyst. Environ., 121, 121-134, 2007.

Suyker, A. and Verma, S.: Year-round observations of the net ecosystem exchange of carbon dioxide in a native tallgrass prairie, Glob. Change Biol., 7, 279-289, 2001.

Suyker, A. E., Verma, S. B., Burba, G. G., Arkebauer, T. J., Walters, D. T., and Hubbard, K. G.: Growing season carbon dioxide exchange in irrigated and rainfed maize, Agr. Forest Meteorol., 124, 1-13, 2004.

Valentini, R., Matteucci, G., Dolman, A. J., Schulze, E. D., Rebmann, C., Moors, E., Granier, A., Gross, P., Jensen, N. O., Pilegaard, K., Lindroth, A., Grelle, A., Bernhofer, C., Grünwald, T., Aubinet, M., Ceulemans, R., Kowalski, A. S., Vesala, T., Rannik, U., Berbigier, P., Loustau, D., Guomundsson, J., Thorgeirsson, H., Ibrom, A., Morgenstern, K., Clement, R., Moncrieff, J., Montagnani, L., Minerbi, S., and Jarvis, P. G.: Respiration as the main determinant of carbon balance in European forests, Nature, 404, 861-865, 2000.

Verma, S. B., Dobermann, A., Cassman, K. G., Walters, D. T., Knops, J. M., Arkebauer, T. J., Suyker, A. E., Burba, G. G., Amos, B., and Yang, H.: Annual carbon dioxide exchange in irrigated and rainfed maize-based agroecosystems, Agr. Forest Meteorol., 131, 77-96, 2005.

Vleeshouwers, L. M. and Verhagen, A.: Carbon emission and sequestration by agricultural land use: a model study for Europe, Glob. Change Biol., 8, 519-530, 2002.

Webb, E. K., Pearman, G. I., and Leuning, R.: Correction of flux measurements for density effects due to heat and water transfer, Q. J. Roy. Meteor. Soc., 106, 85-100, 1980

Wilson, K., Goldstein, A., Falge, E., Aubinet, M., Baldocchi, D., Berbigier, P., Bernhofer, C., Ceulemans, R., Dolman, H., Field, C., Grelle, A., Ibrom, A., Law, B. E., Kowalski, A., Meyers, T., Moncrieff, J., Monson, R., Oechel, W., Tenhunen, J., Valentini, R., and Verma, S.: Energy balance closure at FLUXNET sites, Agr. Forest Meteorol., 113, 223-243, 2002.

30 Wilson, K. B. and Baldocchi, D. D.: Comparing independent estimates of carbon dioxide exchange over 5 years at a deciduous forest in the southeastern United States, J. Geophys. Res., 106(D24), 34167-134178, 2001.

BGD

6, 2755-2784, 2009

\section{Effect of land use on carbon dioxide, water vapour and energy exchange}

N. Jarosz et al.

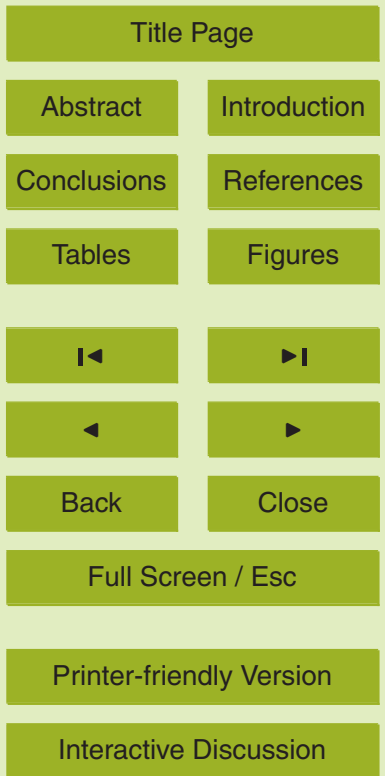




\section{BGD}

6, 2755-2784, 2009

\section{Effect of land use on carbon dioxide, water vapour and energy exchange}

Table 1. Site characteristics including canopy height $\left(h_{c}\right)$ and EC measurements height $\left(h_{\mathrm{EC}}\right)$ during the 2005 CERES campaign.

\begin{tabular}{|c|c|c|c|c|c|c|c|c|}
\hline Site & Abbreviations & Ecosystem & Vegetation type & Coordinates, altitude & $\begin{array}{r}\text { surface } \\
\text { area (ha) }\end{array}$ & $h_{c}(\mathrm{~m})$ & $\begin{array}{l}h_{\mathrm{EC}} \\
(\mathrm{m})\end{array}$ & Citation \\
\hline Bilos & BIL & clearcut forest & grasses & $44^{\circ} 30^{\prime} \mathrm{N}, 0^{\circ} 57^{\prime} \mathrm{W}, 38 \mathrm{~m}$ & 60 & $0-0.1$ & 6 & Kowalski et al. (2003) \\
\hline Le Bray & LBR & mature forest & maritime pines & $44^{\circ} 43^{\prime} 1.6^{\prime \prime} \mathrm{N}, 0^{\circ} 46^{\prime} 9.5^{\prime \prime} \mathrm{W}, 62 \mathrm{~m}$ & 16 & $20.8-21.1$ & 41 & $\begin{array}{l}\text { Berbigier et al. (2001) } \\
\text { Jarosz et al. (2008) }\end{array}$ \\
\hline Auradé & AUR & cropland & oil seed rape & $43^{\circ} 54^{\prime} 97^{\prime \prime} \mathrm{N}, 01^{\circ} 10^{\prime} 61^{\prime \prime} \mathrm{E}, 245 \mathrm{~m}$ & 23.5 & $1.2-1.4$ & 2.8 & Béziat et al. (2008) \\
\hline Couhins & $\mathrm{COU}$ & cropland & vineyard & $44^{\circ} 45^{\prime} \mathrm{N}, 0^{\circ} 33^{\prime} \mathrm{W}, 25 \mathrm{~m}$ & 6 & $0.8-1.4$ & 3 & - \\
\hline Cape Sud & CSB & cropland & bean & $44^{\circ} 24.00^{\prime} \mathrm{N}, 0^{\circ} 35.85^{\prime} \mathrm{W}, 70 \mathrm{~m}$ & 44 & $0.1-0.5$ & 2 & - \\
\hline Cape Sud & CSM & cropland & maize & $44^{\circ} 25^{\prime} \mathrm{N}, 0^{\circ} 37^{\prime} \mathrm{W}, 70 \mathrm{~m}$ & 87 & $0-1.2$ & 4 & - \\
\hline Lamasquère & LAM & cropland & triticale & $43^{\circ} 49^{\prime} 65^{\prime \prime} \mathrm{N}, 01^{\circ} 23^{\prime} 79^{\prime \prime} \mathrm{E}, 180 \mathrm{~m}$ & 32.3 & $0.8-1.2$ & 3.6 & Béziat et al. (2008) \\
\hline Marmande & MAR & cropland & maize & $44^{\circ} 27.84^{\prime} \mathrm{N}, 0^{\circ} 11.76^{\prime} \mathrm{E}, 21 \mathrm{~m}$ & 12 & $0-2.1$ & 3 & - \\
\hline Saint-Sardos & SAR & cropland & maize & $43^{\circ} 53^{\prime} 45^{\prime \prime} \mathrm{N}, 1^{\circ} 06^{\prime} 42^{\prime \prime} \mathrm{E}, 187 \mathrm{~m}$ & 7.3 & $0-1.3$ & 6 & - \\
\hline $\begin{array}{l}\text { SMOSREX } \\
\text { (Le Fauga) }\end{array}$ & FAU & grassland & grasses & $43^{\circ} 23^{\prime} 07^{\prime \prime} \mathrm{N}, 1^{\circ} 17^{\prime} 32^{\prime \prime} \mathrm{E}, 186 \mathrm{~m}$ & 1 & $0.3-0.5$ & 3.5 & $\begin{array}{l}\text { Calvet et al. (2004) } \\
\text { De Rosnay et al. (2006) }\end{array}$ \\
\hline
\end{tabular}

N. Jarosz et al.

Title Page

Abstract Introduction

Conclusions

References

Tables

Figures

14

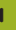

Back

Full Screen / Esc

Printer-friendly Version

Interactive Discussion 
Table 2. Statistics surface energy balance closure for the forest sites (LBR and BIL), the vineyard (COU), the winter crops (AUR and LAM), the summer crops (CSM, CSB, MAR and SAR) and the grassland (FAU). The net radiation $(\mathrm{Rn})$ balance is regressed on the sum of its energy components, latent heat flux $(L E)$, sensible heat flux $(H)$, soil heat flux $(G)$ and canopy heat storage $(S)$.

\begin{tabular}{lrrrrl}
\hline Location & Slope & Intercept & \multicolumn{1}{c}{$r^{2}$} & $n$ & Mean \pm se \\
\hline LBR & 0.87 & 15.33 & 0.92 & 1441 & $\begin{array}{l}\text { Rn: } 175.35 \pm 14.59 \\
\text { Sum: } 167.47 \pm 13.20\end{array}$ \\
BIL & 0.86 & 11.42 & 0.93 & 1527 & $\begin{array}{l}\text { Rn: } 134.40 \pm 9.43 \\
\text { Sum: } 127.55 \pm 8.45\end{array}$ \\
AUR & 0.74 & 5.59 & 0.97 & 1566 & $\begin{array}{l}\text { Rn: } 186.78 \pm 12.47 \\
\text { Sum: } 144.67 \pm 9.45\end{array}$ \\
COU & 0.76 & 2.19 & 0.96 & 1699 & $\begin{array}{l}\text { Rn: } 150.93 \pm 10.38 \\
\text { Sum: } 117.07 \pm 8.06\end{array}$ \\
CSB & 0.71 & 4.6 & 0.93 & 1166 & $\begin{array}{l}\text { Rn: } 160.17 \pm 13.29 \\
\text { Sum: } 169.64 \pm 9.74\end{array}$ \\
CSM & 0.84 & -28.28 & 0.94 & 1428 & $\begin{array}{l}\text { Rn: } 207.32 \pm 11.71 \\
\text { Sum: } 145.83 \pm 10.13\end{array}$ \\
LAM & 0.87 & -0.91 & 0.98 & 1493 & $\begin{array}{l}\text { Rn: } 199.91 \pm 12.82 \\
\text { Sum: } 172.21 \pm 11.22\end{array}$ \\
MAR & 0.92 & 10.72 & 0.95 & 1624 & $\begin{array}{l}\text { Rn: } 163.50 \pm 11.22 \\
\text { Sum: } 161.58 \pm 10.64\end{array}$ \\
SAR & 0.55 & 22.70 & 0.94 & 920 & $\begin{array}{l}\text { Rn: } 148.83 \pm 14.78 \\
\text { Sum: } 104.04 \pm 8.34\end{array}$ \\
FAU & 0.75 & 7.3 & 0.92 & 1346 & $\begin{array}{l}\text { Rn: } 202.30 \pm 12.08 \\
\text { Sum: } 159.33 \pm 9.46\end{array}$ \\
\hline
\end{tabular}

BGD

$6,2755-2784,2009$

Effect of land use on carbon dioxide, water vapour and energy exchange

N. Jarosz et al.

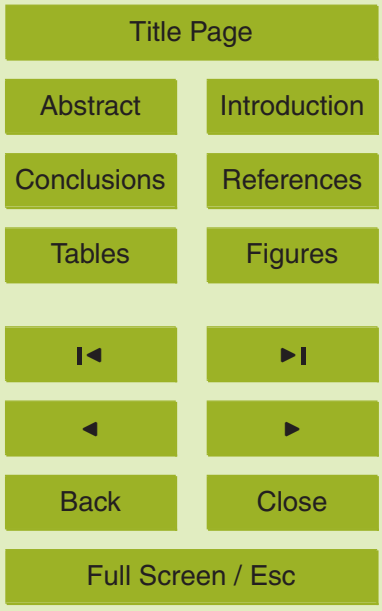

Printer-friendly Version

Interactive Discussion 


\section{BGD}

6, 2755-2784, 2009

Effect of land use on

Table 3. Sum of net ecosystem exchange (NEE), net radiation $(R n)$, sensible heat flux $(H)$, latent heat flux $(L E)$, soil heat flux $(G)$ and evaporation $(E T)$ during the campaign. Bowen ratio, precipitation (Rainfall) and irrigation are also indicated.

\begin{tabular}{lrrrrrrrrrr}
\hline & LBR & BIL & AUR & COU & CSB & CSM & LAM & MAR & SAR $^{*}$ & FAU \\
\hline${\text { NEE }\left(\mathrm{gC} \mathrm{m}^{-2}\right)}-104$ & 29 & -117 & -48 & 33 & -111 & -141 & -231 & -20 & -103 \\
$R n\left(\mathrm{MJ} \mathrm{m}^{-2}\right)$ & 665 & 431 & 541 & 473 & 489 & 578 & 556 & 507 & 384 & 550 \\
$H\left(\mathrm{MJ} \mathrm{m}^{-2}\right)$ & 335 & 270 & 122 & 200 & 124 & 117 & 128 & 163 & 119 & 178 \\
$L E\left(\mathrm{MJ} \mathrm{m}^{-2}\right)$ & 245 & 98 & 269 & 189 & 190 & 275 & 294 & 264 & 163 & 245 \\
$G\left(\mathrm{MJ} \mathrm{m}^{-2}\right)$ & 46 & 34 & 28 & -19 & 52 & 8 & 46 & 75 & 3 & 9 \\
Bowen ratio & 1.37 & 2.76 & 0.45 & 1.06 & 0.66 & 0.43 & 0.43 & 0.62 & 0.73 & 0.73 \\
$E T(\mathrm{~mm})$ & 100 & 40 & 110 & 77 & 77 & 112 & 120 & 106 & 66 & 99 \\
Rainfall $(\mathrm{mm})$ & 10 & 13 & 36 & 14 & 8 & 8 & 31 & 37 & 43 & 51 \\
Irrigation $(\mathrm{mm})$ & - & - & - & - & 35 & 173 & - & 0 & 0 & - \\
\hline
\end{tabular}

carbon dioxide, water vapour and energy exchange

N. Jarosz et al.

${ }^{*} 5$ days are missing at the end of the period considered.

Title Page

Abstract

Introduction

Conclusions

References

Tables

Figures

14

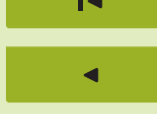

Back

Close

Printer-friendly Version

Interactive Discussion 
BGD

6, 2755-2784, 2009

Effect of land use on carbon dioxide, water vapour and energy exchange

Table 4. Water use efficiency (WUE) defined as the regression slope between $\mathrm{CO}_{2}$ fluxes and evaporation ( $\mathrm{mg} \mathrm{CO}_{2} \mathrm{~g} \mathrm{H}_{2} \mathrm{O}^{-1}$ ).

\begin{tabular}{lrc}
\hline Location & Slope & $r^{2}$ \\
\hline LBR & -9.1 & 0.70 \\
BIL & -4.3 & 0.15 \\
AUR & -7.5 & 0.61 \\
COU & -5.2 & 0.55 \\
CSB & -4.5 & 0.21 \\
CSM & -10.3 & 0.58 \\
LAM & -9.9 & 0.71 \\
MAR & -12.6 & 0.59 \\
SAR & -3.9 & 0.25 \\
FAU & -7.6 & 0.67 \\
\hline
\end{tabular}

N. Jarosz et al.

Title Page

Abstract

Introduction

Conclusions

References

Tables

Figures

14

$\rightarrow$ I

4

Back

Close

Full Screen / Esc

Printer-friendly Version

Interactive Discussion 


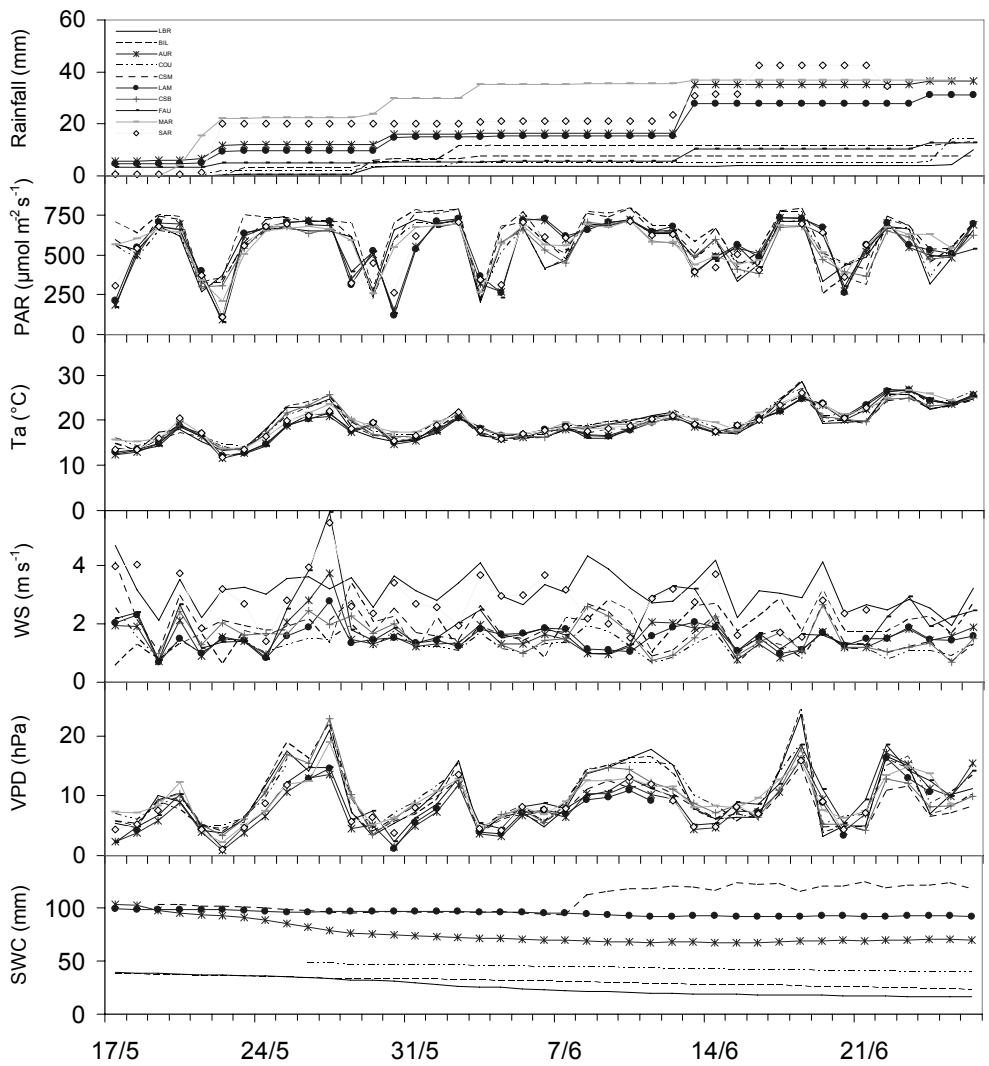

Fig. 1. Cumulated rainfall, daily means of photosynthetically active radiation (PAR), air temperature $(\mathrm{Ta})$, wind speed (WS), vapour pressure deficit (VPD) and soil water content (SWC) from 17 May to 26 June 2005 at all sites of the CERES campaign.

\section{BGD}

$6,2755-2784,2009$

Effect of land use on carbon dioxide, water vapour and energy exchange

N. Jarosz et al.

\section{Title Page}

\section{Abstract}

Introduction

Conclusions

References

Tables

Figures

14

$\rightarrow$

4

Back

Close

\section{Full Screen / Esc}

Printer-friendly Version

Interactive Discussion 


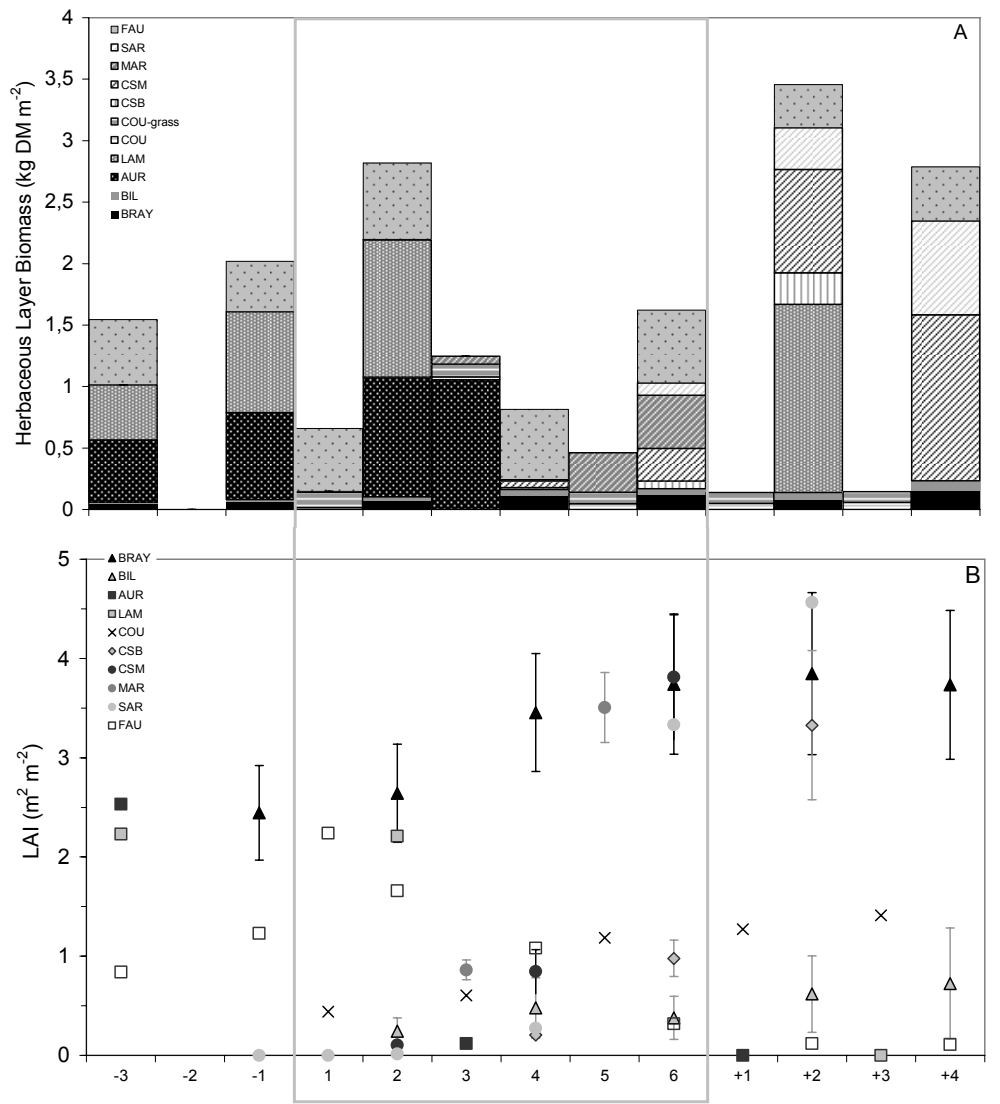

Fig. 2. (A) Herbaceous layer biomass and (B) leaf area index (LAI) from 27 April to 20 July. The CERES experiment is delineated with grey rectangle. Bars give $5 \% \mathrm{Cl}$ on mean values.

\section{BGD}

6, 2755-2784, 2009

Effect of land use on carbon dioxide, water vapour and energy exchange

N. Jarosz et al.

\section{Title Page}

\section{Abstract}

Conclusions

Tables

14

4

Back
Introduction

References

Figures

$\rightarrow 1$

$\checkmark$

Close
Full Screen / Esc

Printer-friendly Version

Interactive Discussion 

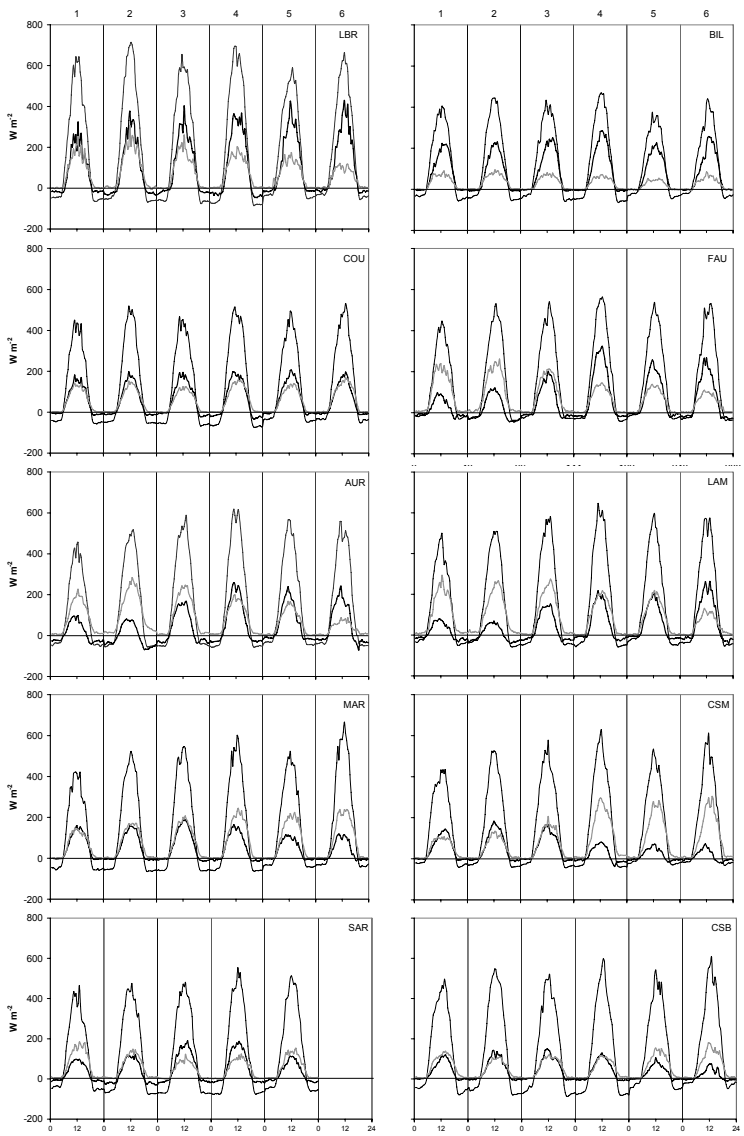

BGD

6, 2755-2784, 2009

Effect of land use on carbon dioxide, water vapour and energy exchange

N. Jarosz et al.

Title Page

Abstract Introduction

Conclusions

References

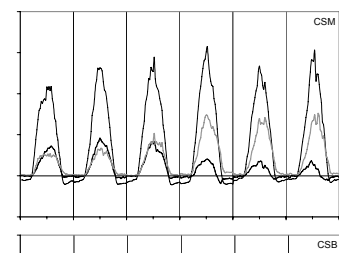

Tables

Figures

14

-I

4

Back

Close

Full Screen / Esc

Fig. 3. Mean daily course of net radiation ( $R n$, thin dark line), sensible heat flux ( $H$, bold dark line) and latent heat flux ( $L E$, bold grey line) above the ten ecosystems during the six weeks of the experiment (numbered from 1 to 6 ). 
BGD
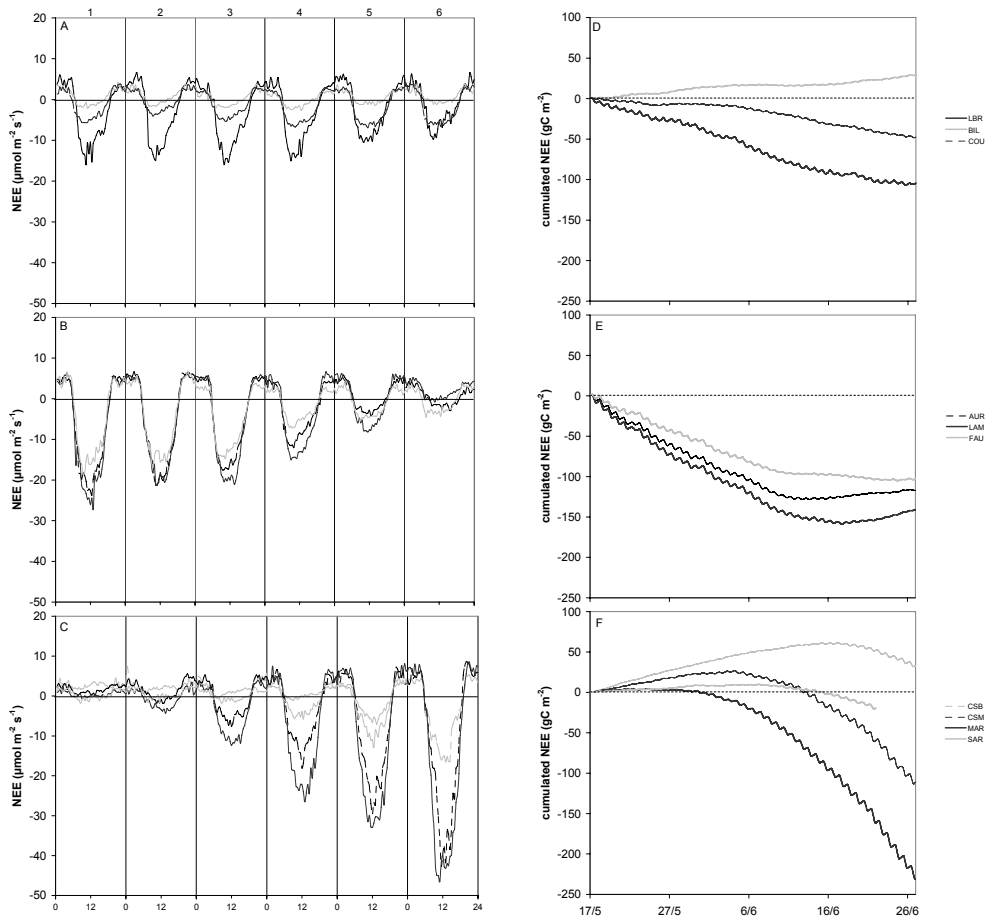

6, 2755-2784, 2009

Effect of land use on carbon dioxide, water vapour and energy exchange

N. Jarosz et al.

Title Page

Abstract Introduction

Conclusions References

Tables Figures

14 - I

4

Back

Close

\section{Full Screen / Esc}

Printer-friendly Version

Interactive Discussion 